\title{
Multifarious activities of cellulose degrading bacteria from Koala (Phascolarctos cinereus) faeces
}

\author{
Surender Singh ${ }^{1 *}$, Palanisami Thavamani ${ }^{2,3,4}$, Mallavarapu Megharaj ${ }^{2,3,4}$ and Ravi Naidu $u^{2,3,4}$
}

\begin{abstract}
Cellulose degrading bacteria from koala faeces were isolated using caboxymethylcellulose-Congo red agar, screened in vitro for different hydrolytic enzyme activities and phylogenetically characterized using molecular tools. Bacillus sp. and Pseudomonas sp. were the most prominent bacteria from koala faeces. The isolates demonstrated good xylanase, amylase, lipase, protease, tannase and lignin peroxidase activities apart from endoglucanase activity. Furthermore many isolates grew in the presence of phenanthrene, indicating their probable application for bioremediation. Potential isolates can be exploited further for industrial enzyme production or in bioremediation of contaminated sites.
\end{abstract}

Keywords: Koala, cellulase, enzymes, biofuel, phenanthrene

\section{Background}

The koala (Phascolarctos cinereus) is an arboreal herbivorous marsupial native to Australia and they feed almost exclusively on eucalyptus leaves. Eucalyptus leaves are low in protein, high in recalcitrant substances like lignin, cellulose, tannin and essential oils that are toxic to most species $[1,2]$. Both aerobic and anaerobic bacteria are the main degraders of eucalyptus leaves in the hindgut of koala [3] and this process requires the activity of cellulases, hemicellulases, ligninases, tannase and other enzymes that are of high biotechnological interest. Intensive studies have been undertaken on the gut microflora of the koala [4-6]. Osawa et al. [7] and Nemoto et al. [8] reported that groups of streptococci and enterobacteria, both of which could degrade the protein complexed with tannin, were the most predominant members of koalas' facultative anaerobic faecal flora. Recently, Peterson et al. $[9,10]$ isolated a number of fungi from koala faeces indicating diverse enzyme activities against recalcitrant substrates such as cellulose and lignin. However, little work has been done on trying to understand the genetic and functional diversity of faecal bacteria other than tannin degraders like cellulose degrading ones. In recent times bacterial cellulases have garnered attention due to their robust ability to inhabit a wide variety of extreme environments, and the enzymes produced by these are stable in

\footnotetext{
* Correspondence: ssriari@gmail.com

${ }^{1}$ Division of Microbiology, Indian Agricultural Research Institute, New Delhi 110012, India

Full list of author information is available at the end of the article
}

such harsh environments during various industrial applications [11]. This means that the processing costs can be cut.

PCR-based DNA-typing methods like 16S rRNA gene sequencing for culturable bacteria are currently universally applicable, simple and rapid. In the meantime denaturing gradient gel electrophoresis (DGGE) coupled with sequence analysis of $16 \mathrm{~S}$ rRNA gene has emerged as a useful technique for studying unculturable microorganisms from environmental samples [12]. However, these molecular techniques do not explain the functional activities of the microorganisms in different biological niches. Consequently in this study we have made an attempt to understand the phylogenetic and functional diversity of culturable cellulose degrading bacteria inhabiting the koala faeces using molecular and other biochemical methods.

\section{Methods}

\section{Collection of sample}

We didn't use animals in this experiment. Koala faeces were obtained from Adelaide Zoo, South Australia with permission of Zoo authorities and no animal was harmed during the process. The faeces were collected by hand, using clean disposable gloves, and placed into a clean sterile plastic bag. The faecal pellets were lightly brushed to remove soil and the upper layer of these pellets was removed by scraping them with a sterile razor to detach any other foreign material. 
Isolation and enumeration of cellulose degrading bacteria Bacteria were extracted from the faeces samples by blending $1 \mathrm{~g}$ wet wt of the sample with $9 \mathrm{ml}$ of Tween buffer ( $1 \%$ Tween 80 and $0.9 \% \mathrm{NaCl})$ for 1 min before serial dilution. Bacterial strains were grown and isolated at 30 and $37{ }^{\circ} \mathrm{C}$ by plating on CMC-Congo red agar for enumeration of cellulose degraders by using the modified Hendricks method [13]. This medium contains $0.05 \%$ $\mathrm{K}_{2} \mathrm{HPO}_{4}, 0.025 \% \mathrm{MgSO}_{4}, 0.188 \% \mathrm{CMC}$ sodium salt, $0.02 \%$ Congo red, $0.02 \%$ gelatine, $0.05 \%$ yeast extract and $1.5 \%$ agar. Morphologically different isolates with a halo zone around the colonies were selected and purified for genotypic and enzymatic studies.

\section{Qualitative screening of isolates for hydrolytic enzyme production and bioremediation potential}

All isolates were screened for production of each enzyme on $1.8 \%(\mathrm{w} / \mathrm{v})$ agar plates containing one of the following substrates (supplied by Sigma-Aldrich, USA, unless otherwise stated): beech xylan $(0.5 \% \mathrm{w} / \mathrm{v})$ for xylanases; CMC sodium salt $(0.5 \% \mathrm{w} / \mathrm{v})$ for endoglucanases [14]; gelatin $(1 \% \mathrm{w} / \mathrm{v})$ for proteases [15]; starch $(1 \% \mathrm{w} / \mathrm{v})$ for amylases [16] and Rhodamine B lipase agar for lipases [17]. All plates contained minimal medium salts consisting of: $\mathrm{KH}_{2} \mathrm{PO}_{4}(1.5 \% \mathrm{w} / \mathrm{v}),\left(\mathrm{NH}_{4}\right)_{2} \mathrm{SO}_{4}$ $(0.5 \% \mathrm{w} / \mathrm{v}), \mathrm{MgSO}_{4} \cdot 7 \mathrm{H}_{2} \mathrm{O}(0.06 \% \mathrm{w} / \mathrm{v})$ and $\mathrm{CaCl}_{2} \cdot 2 \mathrm{H}_{2} \mathrm{O}$ $(0.06 \% \mathrm{w} / \mathrm{v})$. Tannase activity was detected employing the modified method devised by Osawa [5] in which nutrient agar was used in place of brain heart infusion agar. Hydrolysis capacity (HC) index for all ten isolates was calculated by dividing the diameter of the clear zone around the colony with bacterial colony diameter [18].

To evaluate the bioremediation potential, all cultures were grown in $50 \mathrm{ml}$ mineral medium [19] supplemented with $100 \mathrm{ppm}$ phenanthrene under shaking conditions $(140 \mathrm{rpm})$ at $30{ }^{\circ} \mathrm{C}$ for 7 days. To raise inoculums, all the isolates were grown in Luria broth at $30{ }^{\circ} \mathrm{C}$ for $24 \mathrm{hrs}$, centrifuged (6000 rpm for $5 \mathrm{~min}$ ) and pellet was washed three times with normal saline. Pellet was resuspended in normal saline and $2 \mathrm{ml}$ inoculum $\left(\mathrm{OD}_{600} 0.8\right)$ was added to each flask. Any increase in $\mathrm{OD}_{600}$ was taken as an indication of bacterial growth and bioremediation potential [20].

\section{Genomic DNA extraction and 16S rRNA gene PCR amplification}

Genomic DNA was extracted from all the isolates using the ultra clean microbial DNA isolation kit (Mo Bio, USA), following the manufacturer's protocol. DNA preparations were visualized after electrophoresis in a $1.0 \%$ agarose gel in $1 \mathrm{x}$ TBE buffer to assess their integrity and then stored at $-80{ }^{\circ} \mathrm{C}$ prior to PCR amplification.

PCR amplification of 16S rRNA gene sequencing of isolated bacteria was done using universal primer pair consisting of $8 \mathrm{~F}$ (AGAGTTTGATCCTGGCTCAG) and 1541R (AAGGAGGTGGATCCANCCRCA) [21]. The final volume consisting of the reaction mixture of $50 \mu \mathrm{l}$ contained $10 \mu \mathrm{l}$ of Go Taq Buffer, $2.5 \mu \mathrm{l}$ of $\mathrm{MgCl}_{2}$ $(25 \mathrm{mM}), 1 \mu \mathrm{l}$ of dNTP, $1 \mu \mathrm{l}$ of each primer, $2 \mu \mathrm{l}$ (500 ng) template DNA and $0.25 \mathrm{U}$ of Taq polymerase. The amplification was done on Bio-Rad My cycler (Initial denaturation at $94{ }^{\circ} \mathrm{C}$ for 5 min followed by 32 cycles of $94{ }^{\circ} \mathrm{C}$ for $1 \mathrm{~min}, 56{ }^{\circ} \mathrm{C}$ for $1 \mathrm{~min}$ and extension at $72{ }^{\circ} \mathrm{C}$ and final extension at 72 for $10 \mathrm{~min}$ ).

\section{DNA sequencing and phylogenetic analysis}

DNA sequencing of the purified PCR product was carried out by SouthPath at Flinders Sequencing Facility, Flinders Medical Centre in Adelaide using Sanger's di-deoxy nucleotide sequencing method. The sequences were compared with those in the GenBank database using the BLAST search program (http://www.ncbi.nlm.nih.gov/). Phylogenetic analysis was performed with the MEGA 5.0 program (Molecular Evolutionary Genetics Analysis, Version 5.0) [22]. The tree topologies were evaluated using bootstrap analyses based on 1000 replicates [23] and phylogenetic trees were inferred using the neighbourjoining method [24].

\section{Results}

The population of cellulose degraders was $4.4 \times 10^{8} \mathrm{cfu}$ per gram of koala faeces. A total of 10 morphologically different colonies were selected from the highest dilution for the diversity studies.

\section{Qualitative screening of isolates for hydrolytic enzyme production and bioremediation potential}

Extracellular enzyme profiles of all the isolates revealed that besides endoglucanase, $40 \%$ of isolates indicated xylanase, lignin peroxidise and amylase activities. The $\mathrm{HCI}$ for all the isolates were calculated and emerged that the isolate $\mathrm{KC} 2$ as well as $\mathrm{KC} 4$ and $\mathrm{KC} 8$ were good producers of endoglucanase (HCI 6.86), xylanase (HCI 4.37) and tannase (HCI 3.95), respectively (Fig. 1a). All the isolates except $\mathrm{KC4}$ demonstrated proteolytic activities with a maximum $\mathrm{HCI}$ of 4.12 by $\mathrm{KC} 10$ isolate $\mathrm{KC} 10$. Besides protease, lipase, lignin peroxidise and tannase activities were also absent in isolate KC4 (Fig. 1b). Eight cultures were able to use phenanthrene as the sole carbon source and grew convincingly well after 7 days of incubation (Table 1).

\section{Molecular characterization and phylogenetic analysis of isolates}

Sequencing of the 16S rRNA gene was done using Sanger's di-deoxy nucleotide sequencing method and the cultures were identified based on percentage similarity ( $>97 \%$ compared with public database sequences, NCBI) 

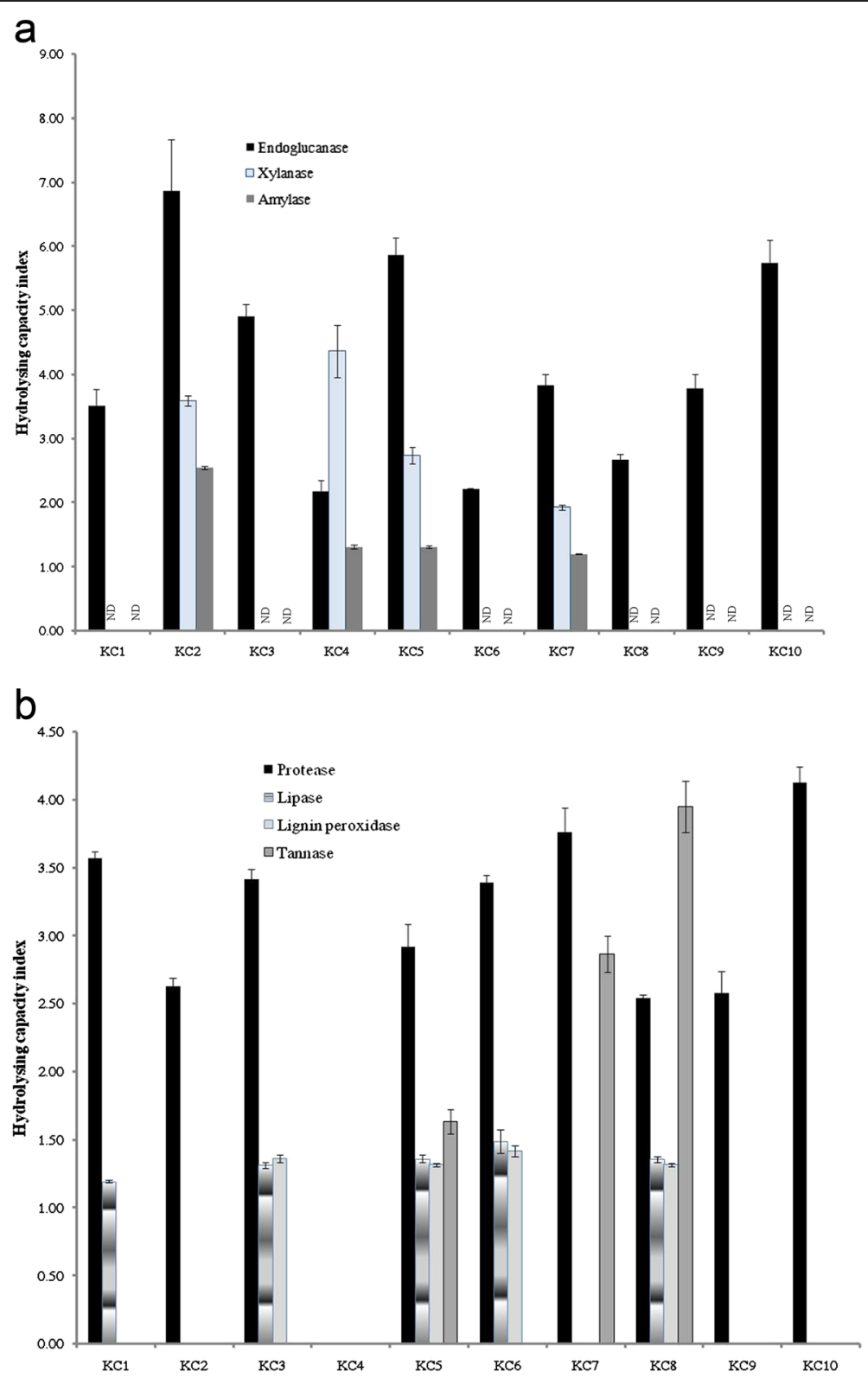

Fig. 1 Hydrolyzing capacity index of the bacterial isolates on agar plates containing the substrate for the target enzyme. a endoglucanase, xylanase and amylase $\mathbf{b}$ Protease, Lipase, lignin peroxidise and tannase. All the assays were carried out at $25^{\circ} \mathrm{C}$ and $48 \mathrm{~h}$ incubation except for lignin peroxidise and tannase (120 h). Error bars indicate standard deviation above and below the mean $(n=3)$

via blastn search (http://www.ncbi.nlm.nih.gov) (Table 2). Out of total ten cultures, 6 belonged to the Bacillus genus while 4 were from phylum gamma proteobacteria and Stenotrophomonas genus. All sequences were submitted to NCBI GeneBank with the accession numbers ranging from JN897275 to JN897284. Neighbour-joining phylogenetic tree indicated that isolates formed coherent clusters with the closet relative available in Genbank public database that exhibited maximum similarity at $16 \mathrm{~S}$ rRNA gene sequence (Fig. 2).

\section{Discussion}

Over the last few decades, 2nd generation biofuels using lignocellulosic feed stocks have received considerable scientific attention due to rising crude oil prices and environmental concerns. Researchers are looking for new isolates with resilient cellulase enzyme system that can reduce the cost of saccharification involved in cheap biofuel production. Digestive tracts of herbivorous animals have always attracted researchers as potential sources of bacteria with unique properties [25-27] and many new 
Table 1 Utilization of phenanthrene (100 ppm) by different isolates

\begin{tabular}{llc}
\hline Isolate & & Growth $(\mathrm{OD} 600 \mathrm{~nm})$ \\
\hline $\mathrm{KC1}$ & + & 0.23 \\
$\mathrm{KC2}$ & ++ & 0.76 \\
$\mathrm{KC} 3$ & + & 0.20 \\
$\mathrm{KC4}$ & - & 0.00 \\
$\mathrm{KC5}$ & + & 0.10 \\
$\mathrm{KC6}$ & - & 0.00 \\
$\mathrm{KC7}$ & ++ & 0.63 \\
$\mathrm{KC} 8$ & + & 0.28 \\
$\mathrm{KC9}$ & + & 0.31 \\
$\mathrm{KC10}$ & + & 0.21 \\
\hline
\end{tabular}

Growth was checked by measuring the increase of OD600 $\mathrm{nm}$ for 7 days ++ : OD600 $\mathrm{nm}>0.5,+:$ OD $600 \mathrm{~nm}>0.1,-$ : No growth

promising microorganisms have been isolated from animal faeces $[28,29]$. The koala of all herbivorous animals has peculiar dietary habits in that it feeds exclusively on eucalyptus leaves high in recalcitrant constituents like cellulose, lignin, essential oils and tannin. Cellulose degrading bacteria play an important role in the enzymatic degradation of cellulose present in eucalyptus leaves for releasing the nutrients for energy. While reports concerning the microflora of koala intestine specially tannin-protein degrading microflora are available, there is still a paucity of data on cellulose degrading bacteria from koala faeces.

To our knowledge, this is the first report of cellulose degrading bacteria from koala faeces or gastrointestinal tract. CMC hydrolysis is often used as a test for endoglucanase and $\beta$-glucosidase activity [30]. CMC assay for cellulose degradation is well established and has been used by different workers with or without modifications as an indicator for cellulose degradation [14, 31, 32]. However, all these methods are time-consuming and use either precipitating agents like hexadecyltrimethyl ammonium bromide (HAB) or congo red for flooding the plates to detect the zone of hydrolysis, which makes isolation of the effective isolates very difficult from the same plates. In the present study, we used modified medium in which CMC and congo red was incorporated in the enumeration medium and the cellulose degrading colonies can be clearly distinguished by the presence of zones of clearing from those that did not use CMC.

In the present study, a considerable population of the cellulose degraders was isolated from the koala faeces and interestingly all the cellulose degraders were either from phylum firmicutes (Bacillus) or gamma proteobacteria based on the blast analysis. All the isolates were assigned to respective species by comparing the closet relative from NCBI database. Gamma proteobacteria and firmicutes are among the most commonly isolated bacterium from faecal and intestinal samples of various animals [33-36]. Bacillus and related spp. are also routinely isolated from animal faeces and intestine samples of many vertebrates [33-40]. Similarly, gamma proteobacteria constitute the major population in the gastrointestinal tract and faeces of animals [41-44]. In this analysis all the isolates emanated from these classes with the majority being the Bacillus spp. Interestingly, Pseudomonas poae, a fluorescent bacterium reported earlier from the phyllosphere of grasses [45] was also present in koala faeces. It may have been ingested by the koala as part of their diet and the bacterium adapted to the gastrointestinal environment forming a symbiotic association with koala.

In addition to cellulase activities, protease, amylase, lipase and tannase activities were also tested for all the isolates. Hydrolysing capacity index used in the study provided a semi-quantitative measure of these bacteria's enzyme production. Most isolates showed more than one extracellular enzyme activity which might be acting synergistically to hydrolyse the toxic eucalyptus leaves in the koala intestine. These enzymes produced by the isolates have various industrial applications. Xylanases are used in paper and pulp production to reduce the use of toxic chlorine compounds that increase pulp brightness

Table 2 Phylogenetic affiliations of culturable bacteria isolated from koala faeces

\begin{tabular}{|c|c|c|c|c|}
\hline Isolate number & Accession number & Specifies Identified & Nearest neighbour & Similarity (\%) \\
\hline KC1 & JN897275 & Pseudomonas sp. & Pseudomonas sp. (HQ727967.1) & 99 \\
\hline KC2 & JN897276 & Bacillus sp. & Bacillus sp. (JN208196.1) & 100 \\
\hline KC3 & JN897277 & Pseudomonas sp & Pseudomonas sp. (HQ727967.1) & 99 \\
\hline KC4 & JN897278 & Bacillus sp. & Bacillus sp. JG-TB2 (FR849914.1) & 100 \\
\hline KC5 & JN897279 & Bacillus sp & Bacillus sp. DG7 (JN208198.1) & 100 \\
\hline KC6 & JN897280 & Bacillus sp. & Bacillus sp. MX47 (JN578480.1) & 100 \\
\hline KC7 & JN897281 & Bacillus subtilis & Bacillus subtilis (JN587510.1) & 100 \\
\hline KC8 & JN897282 & Bacillus sp. & Bacillus sp. JN578480.1 & 100 \\
\hline KC9 & JN897283 & Stenotrophomonas rhizophila & Stenotrophomonas rhizophila strain PCA_13 (JF711015.1) & 99 \\
\hline KC10 & JN897284 & Pseudomonas poae & Pseudomonas poae strain P 527/13 (NR_028986.1) & 99 \\
\hline
\end{tabular}




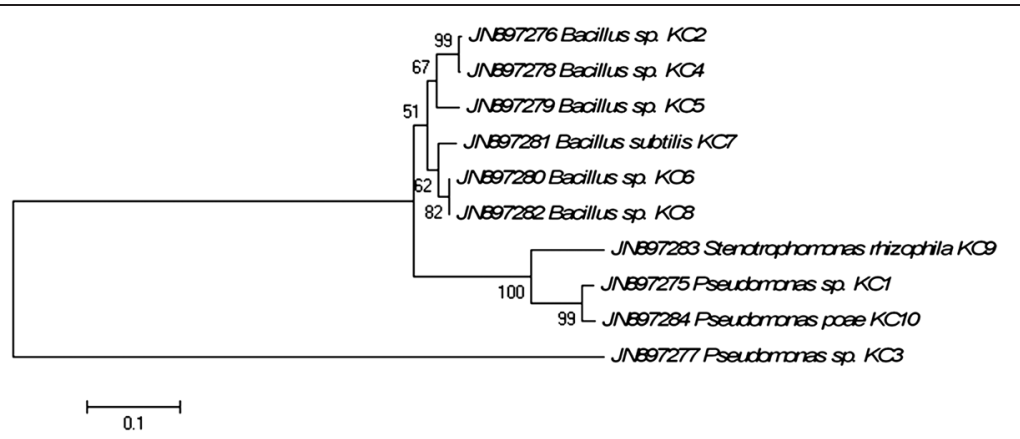

Fig. 2 Phylogenetic tree based on the 16S rRNA gene sequences of different isolates and their closest phylogenetic relatives

[46]. Similarly, amylases are employed in many starch conversion, food and textile industries [47] while tannases have potential to be used in the tea and wine industries [48]. Proteases and lipases have been employed in the textiles, dairy and leather industries in recent decades $[49,50]$.

Many isolates were able to grow in phenanthrene (100 ppm) which is considered to be toxic and carcinogenic compounds that are ubiquitous pollutants in the environment [51]. The capacity to degrade a ring compound like phenanthrene in some cultures might be due to the presence of lignin peroxidase enzyme system which can breakdown a number of pollutants like PAH due to their non-specific action [52]. In other cultures some other pathway of degradation may be involved [53]. These isolates can be exploited further for the bioremediation of other related PAH compounds.

\section{Conclusion}

To conclude, the cellulase degraders isolated from koala faeces have revealed many hydrolytic enzymes that have industrial potential besides cellulase. Furthermore the isolates also possess the ability to grow in the presence of pollutants like phenanthrene, indicating their possible application for bioremediation. Potential isolates will be used in further studies to characterise the enzymes and genes for industrial and bioremediation applications.

\section{Competing interests}

The authors declare that they have no competing interests.

\section{Authors' contributions}

SS and TP collected the samples. SS analyzed the samples. MM and RN conceived and designed the experiments. RN revised the manuscript. All authors interpreted the data, critically revised the manuscript for important intellectual contents and approved the final version.

\section{Acknowledgement}

We thank the Australian Government's Department of Education, Employment and Workplace Relations (DEEWR) for providing an Endeavour Research Award to S. Singh and CERAR, University of South Australia, Mawson Lakes campus. This facilitated the use of designated laboratory facilities.

\section{Author details}

'Division of Microbiology, Indian Agricultural Research Institute, New Delhi 110012, India. ${ }^{2}$ University of Newcastle, Callaghan, New South Wales, Australia. ${ }^{3}$ formerly, Centre for Environmental Risk Assessment and Remediation (CERAR), University of South Australia, Mawson Lakes, Adelaide, South Australia, Australia. ${ }^{4}$ Cooperative Research Centre for Contamination Assessment and Remediation of the Environment (CRC CARE), Adelaide 5095South Australia, Australia.

Received: 30 September 2014 Accepted: 25 May 2015

Published online: 08 July 2015

\section{References}

1. Macauley BJ, Fox LR. Variation in total phenols and condensed tannins in Eucalyptus: leaf phenology and insect grazing. Aust J Ecol. 1980;5:31-5.

2. Cork SJ, Pahl L. The possible influence of nutritional factors on diet and habitat selection by the ringtail possum (Pseudocheirus peregrinus). In: Smith AP, Hume ID, editors. Possums and gliders. Sydney: Australian Mammal Society; 1984. p. 269-76.

3. Cork SJ, Hume ID, Dawson TJ. Digestion and metabolism of a natural foliar diet (Eucalyptus punctata) by an arboreal marsupial, the koala (Phascolarctos cinereus). J Comp Physiol B. 1983;153:181-90.

4. Osawa R, Mitsuoka T. Selective medium for enumeration of tannin-protein complex-degrading Streptococcus spp. in feces of koalas. Appl Environ Microbiol. 1990;56:3609-11.

5. Osawa R. Formation of a clear zone on tannin-treated brain heart infusion agar by a Streptococcus sp. isolated from feces of koalas. Appl Environ Microbiol. 1990;56:829-31.

6. Osawa R, Walsh TP, Cork SJ. Metabolism of tannin-protein complex by facultatively anaerobic bacteria isolated from koala feces. Biodegradation. 1993:4:91-9.

7. Osawa R, Bird PS, Harbrow DJ, Ogimoto K, Seymour GJ. Microbiological studies of the intestinal microflora of the koala, Phascolarctos cinereus. I. Colonisation of the caecal wall by tannin-protein-complex-degrading enterobacteria. Aust J Zool. 1993;41:599-609.

8. Nemoto K, Osawa R, Hirota K, Ono T, Miyake Y. An investigation of gramnegative tannin-protein complex degrading bacteria in fecal flora of various mammals. J Vet Med Sci. 1995;57:921-6.

9. Peterson RA, Bradner JR, Roberts TH, Nevalainen KMH. Fungi from koala (Phascolarctos cinereus) faeces exhibit a broad range of enzyme activities against recalcitrant substrates. Lett Appl Microbiol. 2009;48:218-25.

10. Peterson R, Grinyer J, Nevalainen H. Extracellular hydrolase profiles of fungi isolated from koala faeces invite biotechnological interest. Mycol Prog. 2011;10:207-18.

11. Bhat MK. Cellulases and related enzymes in biotechnology. Biotechnol Adv. 2000;18:355-83.

12. Green SJ, Leigh MB, Neufeld JD. Denaturing Gradient Gel Electrophoresis (DGGE) for microbial community analysis. In: Timmis KN, editor. Handbook of hydrocarbon and lipid microbiology. Berlin, Heidelberg: Springer; 2010. p. 4137-58.

13. Hendricks CW, Doyle JD, Hugley B. A new solid medium for enumerating cellulose-utilizing bacteria in soil. Appl Environ Microbiol. 1995;61:2016-9.

14. Pointing SB. Qualitative methods for the determination of lignocellulolytic enzyme production by tropical fungi. Fungal Divers. 1999;2:17-33. 
15. Jacobs MB, Gerstein MJ. Handbook of Microbiology. Princeton: D Van Nostrand Co. Inc; 1960.

16. Akpan I, Bankole MO, Adesemowo AM. A rapid plate culture method for screening of amylase producing micro-organisms. Biotechnol Technol. 1999;13:411-3.

17. Kouker $G$, Jaeger KE. Specific and sensitive plate assay for bacterial lipases. Appl Environ Microbiol. 1987;53:211-3.

18. Taechapoempol K, Sreethawong T, Rangsunvigit P, Namprohm W, Thamprajamchit B, Rengpipat S, et al. Cellulase-producing bacteria from Thai higher termites, Microcerotermes sp.: enzymatic activities and ionic liquid tolerance. Appl Biochem Biotechnol. 2011;164:204-19.

19. Miller CD, Hall K, Liang YN, Nieman K, Sorensen D, Issa B, et al. Isolation and characterization of Polycyclic Aromatic Hydrocarbon-degrading Mycobacterium isolates from soil. Microb Ecol. 2004:48:230-8.

20. Ling J, Zhang G, Sun H, Fan Y, Ju J, Zhang C. Isolation and characterization of a novel pyrene-degrading Bacillus vallismortis strain JY3A. Sci Total Environ. 2011:409:1994-2000.

21. Muyzer G, De Waal EC, Uitterlinden AG. MEGA5: profiling of complex microbial populations by denaturing gradient gel electrophoresis analysis of polymerase chain reaction-amplified genes coding for $16 \mathrm{~S}$ rRNA. Appl Environ Microbiol. 1993;59:695-700.

22. Tamura K, Peterson D, Peterson N, Stecher G, Nei M, Kumar S. MEGA5 molecular evolutionary genetics analysis using maximum likelihood, evolutionary distance, and maximum parsimony methods. Mol Biol Evol. 2011;28:2731-9.

23. Felsenstein J. Evolutionary trees from DNA sequences: a maximum likelihood approach. J Mol Evol. 1981;17:368-76.

24. Saitou N, Nei M. The neighbor-joining method: a new method for reconstructing phylogenetic trees. Mol Biol Evol. 1987:4:406-25.

25. Ushakova NA, Belov LP, Varshavski AA, Kozlova AA, Kolganova TV, Boulygina ES, et al. Cellulose decomposition under nitrogen deficiency by bacteria isolated from the intestines of phytophagous vertebrates. Microbiology. 2003;72:356-62.

26. Goel G, Puniya AK, Singh K. Phenotypic characterization of tannin-protein complex degrading bacteria from faeces of goat. Small Rumin Res. 2007;69:217-20.

27. Zhang B, Jiang D, Zhou W, Hao H, Niu T. Isolation and characterization of a new Bacillus sp. 50-3 with highly alkaline keratinase activity from Calotes versicolor faeces. World J Microbiol Biotechnol. 2009;25:583-90.

28. Kim B, Al-Tai AM, Kim SB, Somasundaram P, Goodfellow M. Streptomyces thermocoprophilus sp. nov., a cellulase-free endo-xylanase-producing streptomycete. Int J Syst Evol Microbiol. 2000;50:505-9.

29. Velázquez E, de Miguel T, Poza M, Rivas R, Rosselló-Mora R, Villa TG. Paenibacillus favisporous sp. nov., a xylanolytic bacterium isolated from cow faeces. Int J Syst Evol Microbiol. 2004;54:59-64.

30. Pointing SB, Buswell JA, Jones EBG, Vrijmoed LLP. Extracellular cellulolytic enzyme profiles of five lignicolous mangrove fungi. Mycol Res. 1999;103:696-700.

31. Mahasneh AM, Stewart DJ. A medium for detecting $\beta-(1 \rightarrow 3)$ glucanase activity in bacteria. J Appl Bacteriol. 1980;48:457-8.

32. Teather RM, Wood PJ. Use of Congo red-polysaccharide interactions in enumeration and characterization of cellulolytic bacteria from the bovine rumen. Appl Environ Microbiol. 1982;43:777-80.

33. Sahu NP, Kamra DN. Microbial eco-system of the gastro-intestinal tract of wild herbivorous animals. J Appl Anim Res. 2002;21:207-30.

34. Glad T, Bernhardsen P, Nielsen KM, Brusetti L, Andersen M, Aars J, et al. Bacterial diversity in faeces from polar bear (Ursus maritimus) in Arctic Svalbard. BMC Microbiol. 2010;10:10.

35. Kim HB, Borewicz K, White BA, Singer RS, Sreevatsan S, Tu ZJ, et al. Longitudinal investigation of the age-related bacterial diversity in the feces of commercial pigs. Vet Microbiol. 2011;153:124-33.

36. Jia J, Frantz N, Khoo C, Gibson GR, Rastall RA, McCartney AL. Investigation of the faecal microbiota of geriatric cats. Lett Appl Microbiol. 2011;53:288-93.

37. Akbalik G, Gunes H, Yavuz E, Yasa I, Harsa S, Elmaci ZS, et al. Identification of extracellular enzyme producing alkalophilic bacilli from Izmir province by 16S-ITS rDNA RFLP. J Appl Microbiol. 2004;97:766-73.

38. Lauková A, Simonová M, Strompfová V, Štyriak I, Ouwehand AC, Várady M. Potential of enterococci isolated from horses. Anaerobe. 2008;14:234-6.

39. Balcázar JL, Pintado J, Planas M. Bacillus galliciensis sp. nov., isolated from faeces of wild seahorses (Hippocampus guttulatus). Int J Syst Evol Microbiol. 2010;60:892-5
40. Maheswaran S, Sreeramanan S, Reena Josephine CM, Marimuthu K, Xavier R. Occurrence of Bacillus thuringiensis in faeces of herbivorous farm animals. Afr J Biotechnol. 2010;9:8013-9.

41. Bettelheim KA, Kuzevski A, Gilbert RA, Krause DO, McSweeney CS. The diversity of Escherichia coli serotypes and biotypes in cattle faeces. J Appl Microbiol. 2005;98:699-709.

42. Rada V, Vlková E, Nevoral J, Trojanová I. Comparison of bacterial flora and enzymatic activity in faeces of infants and calves. FEMS Microbiol Lett. 2006;258:25-8

43. Clauss M, Wittenbrink MM, Castell JC, Kienzle E, Dierenfeld ES, Flach EJ, et al. Quantification of enterobacteriaceae in faeces of captive black rhinoceros (Diceros bicornis) in relation to dietary tannin supplementation. J Anim Physiol Anim Nutr. 2008;92:29-34.

44. Johnston MA, Porter DE, Scott Gl, Rhodes WE, Webster LF. Isolation of faecal coliform bacteria from the American alligator (Alligator mississippiensis). J Appl Microbiol. 2010;108:965-73.

45. Behrendt U, Ulrich A, Schumann P. Fluorescent pseudomonads associated with the phyllosphere of grasses; Pseudomonas trivialis sp. nov., Pseudomonas poae sp. nov. and Pseudomonas congelans sp. nov. Int J Syst Evol Microbiol. 2003;53:1461-9.

46. Bajpai P. Biological bleaching of chemical pulps. Crit Rev Biotechnol. 2004:24:1-58

47. de Souza PM, e Magalhães PO. Application of microbial a-amylase in industry—a review. Braz. J Microbiol. 2010;41:850-61.

48. Aguilar CN, Rodríguez R, Gutiérrez-Sánchez G, Augur C, Favela-Torres E, Prado-Barragan LA, et al. Microbial Tannases: advances and perspectives. Appl Microbiol Biotechnol. 2007;76:47-59.

49. Saxena RK, Ghosh PK, Gupta R, Davidson WS, Bradoo S, Gulati R. Microbial lipases: potential biocatalysts for the future industry. Curr Sci. 1999;77:101-15.

50. Rao MB, Tanksale AM, Ghatge MS, Deshpande W. Molecular and biotechnological aspects of microbial proteases. Microbiol Mol Biol Rev. 1998;62:597-635.

51. Wu Y, Luo Y, Zou D, Ni J, Liu W, Teng Y, et al. Bioremediation of polycyclic aromatic hydrocarbons contaminated soil with Monilinia sp.: Degradation and microbial community analysis. Biodegradation. 2008;19:247-57.

52. Leontievsky AA, Myasoedova NM, Baskunov BP, Evans CS, Golovleva LA. Transformation of 2,4,6-trichlorophenol by the white rot fungi Panus tigrinus and Coriolus versicolor. Biodegradation. 2000;11:331-40.

53. Lu XY, Zhang T, Fang HHP. Bacteria-mediated PAH degradation in soil and sediment. Appl Microbiol Biotechnol. 2011;89:1357-71.

\section{Submit your next manuscript to BioMed Central and take full advantage of:}

- Convenient online submission

- Thorough peer review

- No space constraints or color figure charges

- Immediate publication on acceptance

- Inclusion in PubMed, CAS, Scopus and Google Scholar

- Research which is freely available for redistribution 